MAKING HERETICS 
This page intentionally left blank 


\title{
MAKING HERETICS
}

MILITANT PROTESTANTISM AND FREE GRACE IN MASSACHUSETTS, 1636-1641

\author{
Michael P. Winship
}




\section{COPYRIGHT @ 2002 BY PRINCETON UNIVERSITY PRESS}

PUBLISHED BY PRINCETON UNIVERSITY PRESS, 41 WILLIAM STREET, PRINCETON, NEW JERSEY 08540 IN THE UNITED KINGDOM: PRINCETON UNIVERSITY PRESS, 3 MARKET PLACE, WOODSTOCK, OXFORDSHIRE OX20 ISY ALL RIGHTS RESERVED

\section{LIBRARY OF CONGRESS CATALOGING-IN-PUBLICATION DATA}

WINSHIP, MICHAEL P. (MICHAEL PAUL).

MAKING HERETICS : MILITANT PROTESTANTISM AND FREE GRACE IN MASSACHU-

SETTS, 1636-1641 / MICHAEL P. WINSHIP

$$
\text { P. CM. }
$$

INCLUDES BIBLIOGRAPHICAL REFERENCES AND INDEX.

ISBN 0-691-08943-4 (ALK. PAPER)

1. PURITANS-MASSACHUSETTS-HISTORY-17TH CENTURY.

2. PROTESTANTISM-MASSACHUSETTS-HISTORY-17TH CENTURY.

3. ANTINOMIANISM-MASSACHUSETTS-HISTORY OF DOCTRINES-

17TH CENTURY. 4. MASSACHUSETTS-HISTORY-COLONIAL PERIOD, CA. 1600-1775.

5. MASSACHUSETTS-POLITICS AND GOVERNMENT-TO 1775.

6. MASSACHUSETTS-CHURCH HISTORY-17TH CENTURY. 7. RELIGIOUS PLURALISM-MASSACHUSETTS-HISTORY-17TH CENTURY. 8. RELIGION AND POLITICS-MASSACHUSETTS-HISTORY-17TH CENTURY. I. TITLE.

F67.W7 2002

$277.44^{\prime} 06-\mathrm{dc} 21 \quad 2001036867$

THIS BOOK HAS BEEN COMPOSED IN BERKELEY BOOK MODIFIED TYPEFACE PRINTED ON ACID-FREE PAPER. $\infty$ WWW.PUP.PRINCETON.EDU PRINTED IN THE UNITED STATES OF AMERICA 
For Eleanor, Natban, and Anna 
This page intentionally left blank 